\title{
KEABSAHAN VALIDITAS DATA HASIL PENGECEKAN SERTIPIKAT ELEKTRONIK DAN PENGECEKAN LANGSUNG
}

\author{
DESI NURWIYANTI
}

Universitas Pancasila

desinurwiyanti01@gmail.com

\begin{abstract}
ABSTRAK
Di Indonesia, sertipikat hak-hak atas tanah berlaku sebagai alat bukti yang kuat sebagaimana ditegaskan dalam Pasal 19 ayat (2) huruf c UUPA dan Pasal 32 ayat (1) PP No.24 Tahun 1997 tentang pendaftaran tanah, mengenai keaslian sertipikat serta mengenai data fisik dan data yuridis yang ada didalam sertipikat menimbulkan permasalahan kewenangan dan tanggung jawab BPN dan PPAT, seperti pengecekan sertipikat elektronik yang berlaku saat ini. Dalam tulisan ini permasalah yang diangkat ialah bagaimana tanggung jawab PPAT dalam hal melakukan pengecekan sertipikat melalui sistem pengecekan elektronik dan pengecekan langsung pada kantor pertanahan dan bagaimana kepastian hukum terhadap keabsahan validitas data hasil pengecekan sertipikat melalui sistem pengecekan elektronik dan pengecekan langsung pada kantor pertanahan. Untuk menjawab permasalahan tersebut digunakan metode penelitian hukum normatif. Sehingga didapat simpulan bahwa tanggung jawab PPAT terhadap sertipikat hanya sebatas pengecekan saja, jika saat ini pengecekan sertipikat yang diberlakukan sistem pengecekan elektronik dan didalam aplikasi ATR/BPN menyebutkan "PPAT harus bertanggung jawab atas kebenaran seluruh data yang diinput dalam permohonan dan saat ini menguasai sertipikat asli yang akan didaftarkan", PPAT sendiri tidak mengetahui sertipikat yang dipegang/dikuasainya saat itu asli atau palsu, seharusnya itu bukan tanggung jawab PPAT tetapi BPN. Sedangkan mengenai Keabsahan validitas data hasil pengecekan sertipikat baik pengecekan elektronik atau pengecekan langsung pada kantor pertanahan seharusnya memberikan muatan informasi data yang sesuai, agar masyarakat mendapatkan kepastian hukum terhadap pengecekan sertipikat baik pengecekan elektronik atau pengecekan langsung.
\end{abstract}

Kata kunci: Pengecekan Sertipikat langsung, Pengecekan Sertipikat Elektronik

\section{ABSTRACT}

In Indonesia, land rights certificates act as strong evidence confirmed in Government Regulation No.24 of 1997 regarding land registration, certificates authenticity and physical and juridical data contained in the certificate raises authority and responsibility matters of BPN and PPAT, such as checking the current electronic certificate. This study is how the PPAT responsibility in checking certificates through an electronic checking system and at the land office and how legal certainty about the validity of data validity results from the certificate. The study uses normative legal research methods. Conclusion is PPAT's responsibility for the certificate is limited to checking only, if 
currently the certificate checking applies the electronic system, it should not have been the responsibility of PPAT but BPN. Meanwhile, the validity of the data validity of certificate checking should provide the appropriate data information content, so public has legal certainty on certificate checking, either electronic or direct checking.

\section{Key Words: Direct Certificate Checking, Electronic Certificate Checking}

\section{A. Pendahuluan}

Peraturan Pelaksana dari Undang-Undang Nomor 5 Tahun 1960 tentang Peraturan Dasar Pokok-pokok Agraria (selanjutnya disebut UUPA) tentang Pendaftaran Tanah telah diatur secara tersendiri yaitu di dalam Peraturan Pemerintah Nomor 24 Tahun 1997 tentang Pendaftaran Tanah. "Penyelenggaraan pendaftaran tanah dilaksanakan oleh Pemerintah untuk kepentingan rakyat dalam rangka memberi jaminan kepastian hukum dibidang pertanahan."1 "Oleh karena itu salah satu tujuan pendaftaran tanah adalah agar pihak ketiga dapat mengetahui siapa yang memegang hak atas tanah tersebut, dimana batas-batasnya."2 . Jadi hak-hak atas tanah harus dimohonkan oleh subjek hukum dalam pendaftaran tanah di kantor Badan Pertanahan Nasional (untuk selanjutnya disebut BPN) serta dibantu oleh Pejabat Pembuat Akta Tanah (untuk selanjutnya disebut PPAT) yang berada di wilayah kabupaten/kota. Maka sebagai bentuk penyelenggaraan pendaftaran tanah yang dilakukan oleh subjek hukum, pemerintah akan mengeluarkan "sertipikat", sebagai alat pembuktian yang kuat.

Maksud sebagai alat pembuktian yang kuat adalah bahwa selama tidak dapat dibuktikan sebaliknya data fisik dan data yuridis yang tercantum di dalamnya sebagai data yang benar. Sudah barang tentu data fisik maupun data yuridis yang tercantum dalam sertipikat harus sesuai dengan data yang tercantum dalam buku tanah dan surat ukur yang bersangkutan, karena data itu diambil dari buku tanah dan surat ukur tersebut. Kebenaran yang terkandung dalam sertipikat tersebut harus diterima baik dalam melakukan perbuatan hukum sehari-hari maupun dalam perkara di pengadilan. ${ }^{3}$

Pengecekan sertipikat hak atas tanah atau hak milik atas satuan rumah susun yang biasanya dilakukan dengan sistem datang langsung pada kantor pertanahan, setelah dicek kantor pertanahan setempat memberikan keterangan pada sertipikat atas tanah atau hak milik atas satuan rumah susun berupa cap dengan kalimat keterangan "Telah diperiksa dan sesuai dengan buku tanah pada kantor pertanahan

${ }^{1}$ I Ketut Oka Setiawan (a), Hukum Agraria (Jakarta : Universitas Pancasila, 2020), hlm. 175

${ }^{2}$ Ibid, hlm. 177

${ }^{3}$ Ibid, hlm. 187-188. 
Kota/Kabupaten..., yang di mohon oleh....selaku PPAT, tanggal......., berdasarkan cap dengan kalimat keterangan tersebut, maka PPAT tidak mempunyai tanggung jawab atas keterangan yang telah diberikan oleh kantor pertanahan atau BPN.

Namun sejak adanya pandemi Covid-19, pengecekan yang biasanya dilakukan dengan cara sistem datang langsung pada kantor pertanahan dibeberapa wilayah kabupaten/kota tidak dapat lagi dilakukan, tujuannya untuk mengantisipasi penyebaran Covid-19 maka pelayanan tatap muka dihentikan, untuk menghindari hal itu pemerintahpun tidak tinggal diam, dimana Kementerian Agraria dan Tata Ruang/Badan Pertanahan Nasional (ATR/BPN) mengambil langkah-langkah mitigasi dampak Covid-19, upaya yang dilakukan diantaranya memberikan beberapa stimulasi agar ekonomi di negara Indonesia tidak berdampak begitu kuat. Ada 4 (empat) layanan digital yang telah dilaksanakan oleh Kementerian Agraria dan Tata Ruang/Badan Pertanahan Nasional (ATR/BPN), yaitu Hak Tanggungan Elektronik, Roya, Pengecekan Sertipikat serta Zona Nilai Tanah $($ ZNT $),{ }^{4}$ terbukti dengan dikeluarkannya Surat Edaran Nomor 3/SE-100.TU.03/III/2020 tentang Pelayanan Pertanahan Dalam Rangka Pencegahan Penyebaran Corona Virus Disease 2019 (Covid-19) tanggal 20 Maret 2020 dari Kementerian Agraria Dan Tata Ruang/Badan Pertanahan Nasional Sekretariat Jenderal (untuk selanjutnya disebut Surat Edaran No. 3/SE-100.TU.03/III/2020 tanggal 20 Maret 2020). Pemberlakuan Surat Edaran tersebut dilatarbelakangi dari adanya Peraturan Menteri Agraria dan Tata Ruang/Kepala Badan Pertanahan Nasional Republik Indonesia Nomor 5 Tahun 2017 tentang Layanan Informasi Pertanahan Secara Elektronik (untuk selanjutnya Permen ATR/Kepala BPN No. 5 Tahun 2017).

Dengan adanya Surat Edaran No. 3/SE-100.TU.03/III/2020 tanggal 20 Maret 2020, maka layanan informasi pertanahan secara elektronik mulai dijalankan, salah satunya adalah pengecekan sertipikat elektronik, namun muatan informasi data dalam pengecekan elektronik sering kali memberikan informasi yang tidak sesuai dengan data pada fisik asli sertipikat, bukankah dalam hal ini BPN seharusnya memberikan kepastian hukum terhadap keabsahan validitas data hasil pengecekan

4 Media Indonesia, "Mitigasi Dampak Korona, Kementerian ATR/BPN Berikan Stimulus", diakses dari https://mediaindonesia.com/read/detail/305163-mitigasi-dampak-koronakementerian-atrbpn-berikan-stimulus, pada tanggal 25 Juli 2020 pukul : 13.00 WIB 
sertipikat baik yang dilakukan melalui sistem pengecekan elektronik atau pengecekan langsung pada kantor pertanahan, karena dalam UUPA disebutkan "untuk menjamin kepastian hukum oleh Pemerintah diadakan pendaftaran tanah di seluruh wilayah Republik Indonesia menurut ketentuan yang diatur dengan Peraturan Pemerintah." PPAT yang dalam hal ini tugasnya adalah merupakan perpanjangan tangan dari BPN terkait pendaftaran tanah, namun dengan adanya pengecekan sertipikat melalui sistem pengecekan elektronik tanggung jawabnya diserahkan penuh kepada PPAT, karena didalam aplikasi tersebut terdapat kalimat yang berbunyi "Kementerian ATR/BPN meminta dikesampingkan atas segala akibat hukum yang timbul terkait permohonan pengecekan sertipikat melalui sistem pengecekan elektronik". ${ }^{6}$

Oleh karena itu, maka diperlukan tinjauan secara yuridis terhadap pemberian tanggung jawab kepada PPAT untuk mengakses pengecekan sertipikat melalui sistem pengecekan elektronik. Melalui studi pustaka dengan mempelajari peraturan hukum yang mendasarinya, sehingga permasalahan yang diangkat dalam penulisan ini ialah:

1. Bagaimana tanggung jawab PPAT dalam hal melakukan pengecekan sertipikat melalui sistem pengecekan elektronik dan pengecekan langsung pada kantor pertanahan?

2. Bagaimana kepastian hukum terhadap keabsahan validitas data hasil pengecekan sertipikat melalui sistem pengecekan elektronik dan pengecekan langsung pada kantor pertanahan?

\section{B. Metode Penelitian}

Pendekatan cara memahami masalah dalam penulisan ini secara umum digunakan pendekatan yuridis normatif. Jenis penelitian ini merupakan penelitian deskriptif (descriptive research). Sesuai dengan jenis penelitian dan pendekatan masalah yang dilakukan, maka teknik pengumpulan data yang digunakan adalah Penelitian Kepustakaan (Library Research). "Uraian hasil dari penelitian

\footnotetext{
${ }^{5}$ Indonesia (a), Undang-Undang Republik Indonesia tentang Peraturan Dasar PokokPokok Agraria, UU No. 5 LN Tahun 1960 No. 104, TLN No. 2043, Pasal 19 ayat (1).

${ }^{6}$ Aplikasi Layanan Mandiri (https://htel.atrbpn.go.id/Account/Index)
} 
kepustakaan untuk memperoleh data sekunder (data yang telah dioleh), bisa dalam bentuk bahan primer, sekunder dan tersier", terdiri dari:

1. Bahan hukum primer, yaitu "bahan-bahan hukum yang mengikat" ${ }^{\prime 8}$ seperti Undang-Undang Dasar Negara Republik Indonesia Tahun 1945 (untuk selanjutnya disebut Undang-Undang Dasar 1945); Undang-Undang Republik Indonesia Nomor 5 Tahun 1960 tentang Peraturan Dasar Pokok-pokok Agraria (untuk selanjutnya disebut UUPA); Undang-Undang Nomor 4 Tahun 1996 tentang Hak Tanggungan Atas tanah Beserta Benda-Benda Yang Berkaitan Dengan Tanah (untuk selanjutnya disebut UUHT); UndangUndang Nomor 28 Tahun 2009 tentang Pajak dan Retribusi Daerah (untuk selanjutnya disebut UU No. 28 Tahun 2009); Keputusan Presiden Nomor 25 Tahun 1988 tentang Badan Pertanahan Nasional (untuk selanjutnya disebut Kepres No. 25 Tahun 1988); Keputusan Presiden Nomor 26 Tahun 1988 tentang Badan Pertanahan Nasional (untuk selanjutnya disebut Kepres No. 26 Tahun 1988); Peraturan Pemerintah Republik Indonesia Nomor 10 Tahun 1961 tentang Pendaftaran Tanah (untuk selanjutnya disebut PP No.10 Tahun 1961); Peraturan Pemerintah Republik Indonesia Nomor 24 Tahun 1997 tentang Pendaftaran Tanah (untuk selanjutnya disebut PP No.24 Tahun 1997); Peraturan Pemerintah Nomor 40 Tahun 1996 tentang Hak Guna Usaha, Hak Guna Bangunan dan Hak Pakai Atas Tanah (untuk selanjutnya disebut PP No.40 Tahun 1996); Peraturan Pemerintah Republik Indonesia Nomor 37 Tahun 1998 tentang Peraturan Jabatan Pejabat Pembuat Akta Tanah (untuk selanjutnya disebut PP No. 37 Tahun 1998); Peraturan Pemerintah Nomor 24 Tahun 2016 tentang Perubahan Atas Peraturan Pemerintah Nomor 37 Tahun 1998 tentang Peraturan Jabatan Pejabat Pembuat Akta Tanah (untuk selanjutnya PP No. 24 Tahun 2016); Peraturan Pemerintah Nomor 43 Tahun 2015 tentang Pihak Pelapor dalam Pencegahan dan Pemberantasan Tindak Pidana Pencucian Uang (untuk selanjutnya disebut PP No. 43 Tahun 2015); Peraturan Pemerintah Nomor 34 Tahun 2016 tentang Pajak Penghasilan Atas Penghasilan dari Pengalihan Hak Atas

\footnotetext{
${ }^{7}$ I Ketut Oka Setiawan (b), Modul Metode Penulisan \& Penelitian Hukum, (Jakarta : Universitas Pancasila, 2019), hlm. 41.

${ }^{8}$ Soerjono Soekanto dan Sri Mamudji, Penelitian Hukum Normatif: Suatu Tinjauan Singkat, Cet. Ke-15, (Jakarta: PT. Raja Grafindo Persada, 2013), hlm 13.
} 
Tanah dan/atau Bangunan dan Perjanjian Pengikatan Jual Beli Atas Tanah dan/atau Bangunan Beserta Perubahannya (untuk selanjutnya disebut PP No. 34 Tahun 2016); Peraturan Menteri Agraria/Kepala Badan Pertanahan Nasional Nomor 3 Tahun 1997 tentang Ketentuan Pelaksanaan Peraturan Pemerintah Nomor 24 Tahun 1997 tentang Pendaftaran Tanah (untuk selanjutnya disebut Permeneg Agraria/Kepala BPN No.3 Tahun 1997); Peraturan Menteri Agraria Dan Tata Ruang/Kepala Badan Pertanahan Nasional Republik Indonesia Nomor 5 Tahun 2017 tentang Layanan Informasi Pertanahan Secara Elektronik (untuk selanjutnya disebut Permen ATR/BPN No.5 Tahun 2017); Peraturan Kepala Badan Pertanahan Nasional Republik Indonesia Nomor 5 Tahun 2008 tentang Uraian Tugas Subbagian Dan Seksi Pada Kantor Wilayah Badan Pertanahan Nasional Dan Uraian Tugas Urusan Dan Subseksi Pada Kantor Pertanahan (untuk selanjutnya disebut Perkaban No.5 Tahun 2008); Peraturan Kepala Badan Pertanahan Nasional Nomor 1 Tahun 2016 tentang Ketentuan Pelaksanaan Peraturan Pemerintah Republik Indonesia Nomor 37 Tahun 1998 tentang Peraturan Jabatan Pejabat Pembuat Akta Tanah (untuk selanjutnya disebut Perkaban No.1 Tahun 2016); Surat Edaran Nomor 3/SE-100.TU.03/III/2020 tanggal 20 Maret 2020 tentang Pelayanan Pertanahan dalam Rangka Pencegahan Penyebaran Corona Virus Disease 2019 (Covid-19) (untuk selanjutnya disebut Surat Edaran No. 3/SE-100.TU.03/III/2020); Kitab Undang-Undang Hukum Perdata (Burgerlijk Wetboek).

2. Bahan hukum sekunder, yaitu "bahan-bahan yang erat hubungannya dengan bahan hukum primer dan dapat membantu menganalisis dan memahami bahan hukum primer," contohnya adalah buku yang ditulis oleh para ahli dibidang hukum yang dapat dijadikan sebagai pendapat dari para ahli, artikel, jurnal, skripsi, tesisi dan penulisan ilmiah lainnya.

3. Bahan hukum tersier yaitu "bahan-bahan yang memberikan informasi tentang bahan primer dan bahan sekunder."10 Dalam penulisan ini, bahan hukum tersier yang digunakan adalah Kamus Besar Bahasa Indonesia, abstrak dan jenis-jenis sumber tersier lainnya.

${ }^{9}$ Yamin dan Utji Sri Wulan Wuryandari, Nukilan: Metode Penelitian Hukum, (Jakarta: Universitas Pancasila, 2014), hlm. 29.

${ }^{10} \mathrm{Ibid}$. 
Disamping studi dokumen, juga dilakukan wawancara dengan para pakar seperti dalam bidang keagrariaan dan pertanahan kepada Erwin Yudo Suwono, Notaris dan PPAT kepada E. Betty Budiyanti Moesigit dan Mira Sukoco.

\section{Pembahasan}

1. Tanggung Jawab Pejabat Pembuat Akta Tanah (PPAT) Dalam Melakukan Pengecekan Sertipikat Melalui Sistem Pengecekan Elektronik Dan Pengecekan Langsung Pada Kantor Pertanahan.

Rangkaian kegiatan pendaftaran tanah sebagaimana tersebut diselenggarakan oleh pemerintah yang dalam hal ini adalah BPN dan dalam pelaksanaannya dilakukan oleh kepala kantor pertanahan yang dibantu oleh PPAT dan pejabat lainnya sebagaimana disebutkan dalam Pasal 6 PP No. 24 Tahun 1997. Dengan demikian, maka jelas bahwa PPAT melaksanakan "sebagian kegiatan" pendaftaran tanah dan “sebagian kegiatan' lainnya dilaksanakan oleh kepala kantor pertanahan.

Dari adanya tugas pokok yang diemban oleh PPAT, maka lahirlah kewenangan pada jabatan PPAT untuk membuat akta otentik mengenai perbuatan hukum tertentu. Tanggung Jawab PPAT dalam melakukan pengecekan sertipikat adalah sesuai dengan ketentuan yang ada di dalam Pasal 39 ayat (1) butir a PP No. 24 Tahun 2017. Dari ketentuan tersebut diwujudkan fungsi dan tanggung jawab PPAT sebagai pelaksana pendaftaran tanah, sebelum PPAT menjalankan kewenangannya dalam pelaksanaan pembuatan akta yang menjadi dasar untuk pendaftaran pemindahan hak dan pembebanan hak yang bersangkutan, maka PPAT bertanggung jawab untuk memeriksa syarat-syarat untuk sahnya melakukan perbuatan hukum, antara lain mencocokan data yang terdapat dalam sertipikat dengan daftar-daftar yang ada di kantor pertanahan atau disebut juga dengan pengecekan sertipikat.

Jadi tanggung jawab PPAT terhadap sertipikat sebatas pengecekan saja, karena sertipikat adalah surat tanda bukti hak yang dikeluarkan oleh pemerintah yaitu BPN yang memiliki kewenangan dan bertanggung jawab terhadap data fisik serta data yuridis yang telah dibukukan pada kantor pertanahan setempat. Dengan demikian jelas berdasarkan kewenangan tersebut bahwa PPAT dan BPN memiliki kewenangan berbeda oleh karena itu tanggung jawabnya juga berbeda pula.

Menurut Abdulkadir yang dikutip oleh Hatta Isnaini Wahyu Utomo "setiap organisasi profesi mempunyai acuan mengenai cita-cita dan nilai-nilai 
bersama yang disebut dengan kode etik. Kode etik profesi merupakan produk etika terapan karena dihasilkan berdasarkan penerapan pemikiran etis atau suatu profesi". ${ }^{11}$ Ikatan Pejabat Pembuat Akta Tanah (IPPAT) sebagai organisasi bagi para PPAT wajib memiliki kode etik sebagai representasi nilai moral yang menjadi norma prilaku bagi siapa saja yang menjalankan jabatan PPAT.

Menurut Erwin Yudo Suwono, ${ }^{12}$ Surat Edaran No.3/SE100.TU.03/III/2020 sejak diberlakukannya tanggal 20 Maret 2020 sampai dengan tanggal tanggal 5 April 2020 belum adanya perpanjangannya, namun demikian payung hukum terkait layanan informasi pertanahan secara elektronik yang mendasarinya adalah Permen ATR/Kepala BPN No. 5 Tahun 2017, jadi segala kegiatan yang menggunakan aplikasi digital pertanahan secara elektronik, seperti pengecekan sertipikat, hak tanggungan, roya maupun Zona Nilai Tanah (ZNT) hingga saat ini masih terus berlangsung.

Mira Sukoco menyampaikan, ${ }^{13}$ dalam hal dilakukannya pengecekan sertipikat melalui sistem pengecekan langsung pada kantor pertanahan siapapun pihak-pihak yang berkepentingan dapat melakukan pengecekan sertipikat secara mandiri dengan datang langsung pada kantor pertanahan setempat, namun berbeda dengan sistem pengecekan elektronik dimana dalam aplikasi hanya bisa dilakukan oleh PPAT saja.

Padahal jelas dalam Permen ATR/Kepala BPN No. 5 Tahun 2017 pada Pasal 6 ayat (1) dan (2) disebutkan berturut-turut: ${ }^{14}$

(1) Layanan informasi pertanahan secara elektronik dapat dilakukan setelah data pertanahan tersedia dalam pangkalan data kementerian;

(2) Dalam hal pangkalan data sebagaimana dimaksud pada ayat (1) belum tersedia, permohonan dilakukan secara manual.

Jika mencermati ketentuan tersebut seharusnya jika pemohon dalam layanan informasi pertanahan secara elektronik dalam hal pengecekan sertipikat hanya bisa diakses oleh PPAT saja melalui sistem pengecekan elektronik, itu berarti masyarakat umum dapat melakukan permohonan pengecekan sertipikat

\footnotetext{
${ }^{11}$ Hatta Isnaini Wahyu Utomo, Memahami Peraturan Jabatan Pejabat Pembuat Akta Tanah, (Jakarta : Kencana, 2020), hlm.146.

${ }^{12}$ Erwin Yudo Suwono, wawancara pribadi, Kantor Badan Pertanahan Nasional Kota Administrasi Jakarta Selatan, 17 Desember 2020, Pukul : 13.00 WIB.

${ }^{13}$ Mira Sukoco, wawancara pribadi, Notaris-PPAT di Wilayah Kota Yogyakarta, 8 Desember 2020, Pukul 13.00 WIB.

${ }^{14}$ Indonesia (b), Peraturan Menteri Agraria Dan Tata Ruang / Kepala Badan Pertanahan Nasional Republik Indonesia Nomor 5 Tahun 2017 tentang Layanan Informasi Pertanahan Secara Elektronik, Permen ATR/Kepala BPN No.5 Tahun 2017, Pasal 6 ayat (1) dan (2)
} 
langsung secara manual pada kantor pertanahan. Bahkan hal tersebut juga dipertegas oleh Kementerian ATR/BPN "pengecekan sertipikat elektronik full dari 1 Januari 2021 secara nasional. Jadi pengecekan manual sudah ditutup 100\% (seratus persen) tepat ditanggal 31 Desember 2020 kemarin" ${ }^{\prime 15}$, tentu saja hal ini menyimpang dari ketentuan Permen ATR/Kepala BPN No. 5 Tahun 2017 tersebut.

Pengecekan sertipikat melalui sistem pengecekan elektronik, dimana didalam aplikasi juga menyebutkan bahwa PPAT harus bertanggung jawab terhadap keaslian sertipikat yang diunggah kedalam sistem aplikasi, jika ternyata sertipikat yang diunggah kedalam sistem tersebut palsu, tentu saja hal ini akan menimbulkan masalah hukum untuk PPAT, karena yang melakukan pengecekan sertipikat melalui sistem pengecekan elektronik hanya PPAT saja, padahal PPAT sendiri tidak mengetahui atas sertipikat yang diterimanya dari klien asli atau palsu. Lalu dimana letak perlindungan hukum bagi PPAT, bukankah perlindungan hukum terhadap rakyat bertujuan untuk memberikan keadilan bagi rakyat.

Jika kewenangan PPAT dalam menjalankan tugasnya taat hukum, etis, adil dan bertanggung jawab serta sesuai dengan peraturan perundang-undangan dan kode etik, seharusnya PPAT juga mendapatkan perlindungan hukum terhadap masalah yang seharusnya bukan menjadi tanggung jawabnya. Masalah terhadap pengecekan sertipikat elektronik khususnya prihal keaslian sertipikat yang diterima dari klien, jika pada saat menginput sertipikat ke dalam sistem pengecekan elektronik tersebut ternyata palsu karena ketidaktahuan PPAT atas sertipikat tersebut, disinilah PPAT ingin mendapatkan perlindungan hukum yang seadil-adilnya, karena sertipikat itu sendiri bukan produk buatan PPAT tetapi produk buatan BPN, tetapi kenyataanya didalam aplikasi terkait penginputan permohonan data pengecekan sertipikat sepenuhnya menjadi tanggung jawab PPAT dan mengenyampingkan kementrian ATR/BPN.

Padahal mekanisme tugas dan tanggung jawab yang dijalankan oleh PPAT dalam menjalankan jabatannya telah sesuai dengan kewenangan yang ada dalam

${ }^{15}$ Media Indonesia, "Pengecekan Sertifikat Tanah Full Elektronik Mulai Tahun Ini", diakses dari https://mediaindonesia.com/ekonomi/374493/pengecekan-sertifikat-tanah-fullelektronik-mulai-tahun-ini, pada tanggal 25 Januari 2020 pukul : 17.00 WIB 
peraturan perundang-undangan dan kode etik, dalam hal pengecekan sertipikat secara elektronik PPAT merupakan satu-satunya subjek hukum yang dapat mengakses sistem pengecekan sertipikat elektronik tersebut, maka jika terjadi masalah hukum terhadap PPAT seharusnya mendapatkan perlindungan hukum yang preventif, yang mengarahkan tindakan pemerintah bersikap hati-hati dalam mengambil keputusan atas aturan yang dibuatnya, sehingga tidak terjadi sengketa dikemudian hari, karena wajar saja pada saat aturan hukum tersebut dibuat, PPAT tidak dilibatkan sebelumnya, padahal PPAT memiliki sebagian peran penting dalam pendaftaran tanah, sebagaimana yang tersebut didalam peraturan perundang-undangan.

\section{Kepastian Hukum Terhadap Keabsahan Validitas Data Hasil Pengecekan Melalui Sistem Pengecekan Elektronik Dan Pengecekan Langsung Pada Kantor Pertanahan.}

BPN sebagai alat kelengkapan negara, yang mempunyai bidang tugas di bidang pertanahan dengan unit kerjanya. Oleh karena itu dalam hal penerbitan sertipikat BPN harus menerapkan unsur kehati-hatian dalam menginput data fisik dan data yuridis didalam buku tanah, agar informasi yang diberikan atas keabsahan data sertipikat cukup valid, jika terjadi kesalahan terhadap data fisik dan data yuridis dalam sertipikat, maka secara otomatis pula informasi yang diberikan atas keabsahan data sertipikat tidak menjadi valid, sehingga mengakibatkan terciptanya administrasi pertanahan yang tidak tertib, karena sertipikat adalah produk akhir dari rangkaian proses pendaftaran tanah yang dikeluarkan oleh BPN untuk memberikan kepastian hukum.

Menurut Bellefroid yang dikutip oleh Ade Saptomo ${ }^{16}$ "hukum yang berlaku di suatu masyarakat mengatur tata tertib masyarakat dan didasarkan atas kekuasaan yang ada di dalam masyarakat itu". Dengan kata lain adanya hukum kehidupan masyarakat menjadi lebih teratur dan terarah, karena adanya kepastian hukum, dimana tujuannya agar masyarakat tidak kebingungan terhadap suatu aturan hukum baik dalam pengaturan maupun dalam penegakan hukum, kepastian

${ }^{16}$ Ade Saptomo, Budaya Hukum \& Kearifan Lokal Sebuah Perspektif Perbandingan, (Jakarta : Universitas Pancasila, 2019), hlm. 31. 
hukum sangat terkait dengan keabsahan atau legalitas yang menjadikan hukum nantinya sebagai mahkota.

Pengecekan sertipikat hak atas tanah atau hak milik atas satuan rumah susun melalui sistem pengecekan langsung pada kantor pertanahan yang dilakukan secara manual sesuai prosedur, maka pada fisik asli sertipikat tersebut akan tertera tulisan/cap kalimat keterangan dari kantor pertanahan setempat "Telah diperiksa dan sesuai dengan buku tanah pada kantor pertanahan Kota/Kabupaten........., yang di mohon oleh......... selaku PPAT, tanggal.....", dalam hal ini PPAT menyerahkan sepenuhnya keabsahan validitas data hasil pengecekan sertipikat hak atas tanah atau hak milik atas satuan rumah susun tersebut kepada instansi BPN, tulisan/cap kalimat keterangan dalam sertipikat tersebut dapat memberikan dampak hukum karena adanya kepastian, karena dengan adanya tulisan/cap kalimat keterangan di dalam sertipikat berarti instansi BPN telah memberikan informasi yang sudah di verifikasi sesuai dengan data fisik dan data yuridis yang ada pada kantor pertanahan.

Namun sejak diberlakukannya pengecekan sertipikat melalui sistem pengecekan elektronik, maka pada blanko sertipikat asli tidak tertera tulisan/cap keterangan apapun, namun yang berlaku saat ini adalah pencetakan berkas pengecekan sertipikat, dalam praktiknya PPAT sering kali menemui kendala terhadap muatan informasi data pengecekan sertipikat elektronik yang mana isinya tidak sesuai dengan data yang ada pada fisik sertipikat asli, padahal layanan informasi pertanahan secara elektronik sesuai ketentuan Permen ATR/Kepala BPN No.5 Tahun 2017 adalah proses memberikan informasi secara elektronik meliputi konfirmasi kesesuaian data fisik dan data yuridis sertipikat hak atas tanah serta informasi lainnya dipangkalan data. Informasi kesesuaian data fisik dan data yuridis sertipikat hak atas tanah yang didapat pada pengecekan sertipikat elektronik malah sebaliknya yang mana sering tidak sesuai.

Terkait proses pengecekan sertipikat melalui sistem pengecekan elektronik yang diharapkan dapat memberikan kepastian hukum dan kemudahan pihak-pihak yang berkepentingan, namun ternyata justru sebaliknya, jika terjadi ketidaksesuaian terhadap keabsahan validitas data hasil pengecekan sertipikat melalui sistem pengecekan elektronik prosesnya bisa jauh lebih lama dari pada pengecekan sertipikat secara manual, karena PPAT harus memberitahukan dan 
berkoordinasi dengan kantor pertanahan terlebih dahulu untuk melakukan perbaikan.

Jika menukik kebelakang padahal sudah cukup jelas, bahwa tujuan adanya pendaftaran tanah sebagaimana dimaksud dalam Pasal 3 PP No. 2 Tahun 1997, yaitu untuk menjamin adanya kepastian hukum hak-hak atas tanah. Jaminan kepastian hukum hak-hak atas tanah meliputi: ${ }^{17}$

1. Kepastian hukum atas objek bidang tanahnya, yaitu letak bidang tanah, letak batas-batas dan luasnya (objek hak).

2. Kepastian hukum atas subjek haknya, yaitu siapa yang menjadi pemiliknya (subjek hak) dan

3. Kepastian hukum atas jenis hak atas tanahnya.

Oleh karena itu jika dikaitkan dengan adanya pengecekan sertipikat baik melalui sistem pengecekan langsung pada kantor pertanahan maupun sistem pengecekan elektronik seharusnya instansi BPN yang melakukan proses pendaftaran tanah dapat memberikan informasi yang akurat sesuai dengan daftar-daftar yang ada pada kantor pertanahan setempat baik mengenai data fisik dan data yuridisnya. Namun pada kenyataannya dengan adanya pengecekan sertipikat melalui sistem pengecekan elektronik kepastian hukum terhadap hak-hak atas tanah menjadi kabur, keabsahan validitas data hasil pengecekan sertipikat melalui sistem pengecekan elektronik masih sering kali ditemukan adanya ketidaksesuaian atas layanan informasi data yang diberikan, sehingga dengan kejadian ini akan berdampak secara khusus pada PPAT dan secara umum kepada masyarakat.

Kepastian subjek dan objek hak seperti tersebut sangat diperlukan dalam lalu lintas hukum mengenai hak-hak atas tanah, sehingga oleh pemerintah dikebanyakan negara diselenggarakan suatu sistem keterbukaan atau sistem publisitas. Bukankah kepastian hukum merupakan produk dari hukum atau lebih khusus dari perundang-undangan. Begitu datang hukum maka datanglah kepastian.

\section{Kesimpulan}

1. Tanggung jawab PPAT terhadap sertipikat hanya sebatas pengecekan saja, dengan dilakukannya pengecekan sertipikat baik melalui sistem pengecekan

\footnotetext{
${ }^{17}$ Suardi, Hukum Agraria, (Jakarta : Badan Penerbit Iblam, 2005), hlm.144.
} 
secara elektronik atau pengecekan langsung pada kantor pertanahan adalah untuk mengetahui pada buku tanah bahwa keadaan sertipikat tersebut bersih dan tidak ada sengketa, setelah itu PPAT diberi kewenangan untuk mengkonstantir suatu perbuatan hukum atas tanah antara pihak-pihak ke dalam akta. Oleh karena itu jika saat ini pengecekan sertipikat yang diberlakukan sistem pengecekan elektronik dan didalam aplikasi ATR/BPN menyebutkan "PPAT harus bertanggung jawab atas kebenaran seluruh data yang diinput dalam permohonan dan saat ini menguasai sertipikat asli yang akan didaftarkan", PPAT sendiri tidak mengetahui sertipikat yang dipegang/dikuasainya saat itu asli atau palsu, karena sertipikat adalah ranah kewenangan dan tanggung jawab BPN.

2. Keabsahan validitas data hasil pengecekan sertipikat baik melalui sistem pengecekan elektronik atau pengecekan langsung pada kantor pertanahan adalah untuk memastikan antara sertipikat dan buku tanah di kantor pertanahan atau BPN sudah diverifikasi dan sesuai. Keberlakuan keabsahan validitas data hasil pengecekan sertipikat langsung (manual) dimana dalam blanko sertipikat tertera tulisan/cap kalimat keterangan dari kantor pertanahan setempat "Telah diperiksa dan sesuai dengan buku tanah pada kantor pertanahan Kota/Kabupaten........., yang di mohon oleh.........selaku PPAT, tanggal.....", dengan demikian maka tulisan/cap kalimat keterangan tersebut memberikan dampak kepastian hukum kepada pihak-pihak yang berkepentingan. Namun semenjak diberlakukan pengecekan sertipikat melalui sistem pengecekan elektronik, keberlakuan keabsahan validitas data hasil pengecekannya terletak pada muatan informasi data yang ada didalam sistem aplikasi, tetapi muatan informasi data yang diberikan pada aplikasi ATR/BPN seringkali ditemukan perbedaan dengan datadata yang ada pada fisik sertipikat asli, karena masalah tersebut akhirnya memberikan dampak tidak adanya kepastian hukum, sehingga informasi terhadap lalu lintas pertanahan menjadi tidak valid.

\section{E. Daftar Pustaka}

\section{Buku}

Saptomo, Ade. Budaya Hukum \& Kearifan Lokal Sebuah Perspektif Perbandingan. Jakarta . Universitas Pancasila. 2019. 
Setiawan, I Ketut Oka. Hukum Agraria. Jakarta. Universitas Pancasila. 2020).

Modul Metode Penulisan \& Penelitian Hukum. Jakarta.

Universitas Pancasila. 2019.

Soekanto, Soerjono dan Sri Mamudji. Penelitian Hukum Normatif: Suatu Tinjauan Singkat. Cet. Ke-15. Jakarta. PT. Raja Grafindo Persada. 2013.

Suardi. Hukum Agraria. Jakarta . Badan Penerbit Iblam. 2005.

Utomo, Hatta Isnaini Wahyu. Memahami Peraturan Jabatan Pejabat Pembuat Akta Tanah. Jakarta. Kencana.

Yamin dan Utji Sri Wulan Wuryandari. Nukilan: Metode Penelitian Hukum. Jakarta. Universitas Pancasila. 2014.

\section{Peraturan Perundang-undangan}

Indonesia. Undang-Undang Republik Indonesia Tentang Peraturan Dasar Pokok-Pokok Agraria. UU No. 5 LN No. 104 Tahun 1960. TLN No. 2043.

. Peraturan Peraturan Menteri Agraria Dan Tata Ruang/Kepala Badan Pertanahan Nasional Tentang Layanan Informasi Pertanahan Secara Elektronik. Permen ATR/BPN No.5 Tahun 2017.

. Surat Edaran Tentang Pelayanan Pertanahan dalam Rangka Pencegahan Penyebaran Corona Virus Disease 2019 (Covid19). Surat Edaran No. 3/SE-100.TU.03/III/2020.

\section{Internet}

Media Indonesia. "Mitigasi Dampak Korona, Kementerian ATR/BPN Berikan Stimulus". terdapat pada situs https://mediaindonesia.com/read/detail/305163-mitigasidampak-korona-kementerian-atrbpn-berikan-stimulus.

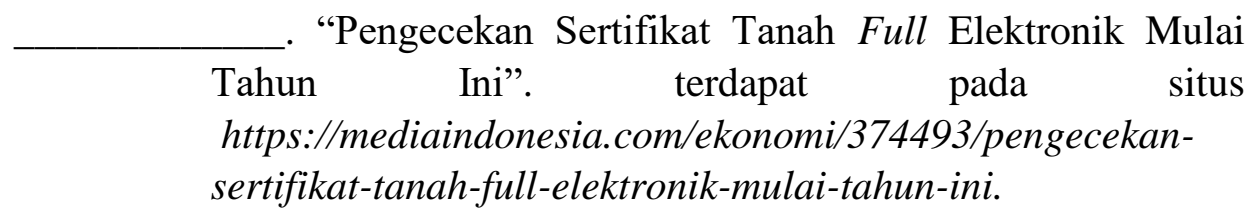

\section{Wawancara}

Wawancara Pribadi kepada Mira Sukoco selaku Notaris-PPAT di Wilayah Kota Yogyakarta, Yogyakarta 8 Desember 2020, Pukul 13.00 WIB. 
Otentik's: Jurnal Hukum Kenotariatan (Vol 3, No. 2, Juni 2021)

p-ISSN 2655-5131 e-ISSN 2685-3612

Wawancara Pribadi kepada Erwin Yudo Suwono selaku Instansi Badan Pertanahan Nasional Kota Administrasi Jakarta Selatan, Jakarta Selatan 17 Desember 2020, Pukul 13.00 WIB. 